\title{
WFSLMS Articles of Association and Bylaws
}

\author{
Adopted November $29^{\text {th }}, 2009$
}

\section{1: Name \& Address}

The name of the Federation is the World Federation of Societies for Laser Medicine and Surgery (WFSLMS). The WFSLMS address will be the same as the current Secretary-General, and the WFSLMS will act as an umbrella society, with the International Society for Laser Surgery and Medicine (ISLSM) as the main partner society

\section{2: Aims}

The WFSLMS aims are:

to provide a forum for cooperation between Member Societies

to promote laser medicine and surgery

to promote medical laser research, development and education

to provide internationally-recognized accreditation, together with the ISLSM, for medical laser specialists

\section{3: Federation Membership}

a) WFSLMS membership is open to any recognised medical laser association, who must then apply to the WFSLMS to become a recognized Member Society.

b) Any medical laser society is welcome to apply for WFSLMS membership, in writing, to the current Secretary-General Once their application is accepted, the new Member Society must report the number of their members to the WFSLMS Secretary-General. If any Member Society behaves badly or causes problems for the WFSLMS then their membership can be withdrawn by the WFSLMS executive.

c) The maximum representatives for Member Societies is 4 , depending on the size of the society membership: from 100 to 600, 1 representative; 601-1100, 2; 1101-2100, 3 and over 2101 members, 4

d) Member Societies may resign from the Federation at any time, in writing to the Secretary-General.

e) If the contact address of a Member Society changes, they must write to the Secretary-General with the new address.

\section{4: Organization of the Federation}

a) Executive Committee

i: There will be 7 members in the Executive Committee: The President, Secretary-General, Assistant Secretary-General, Scientific Secretary, Honorary Treasurer, President-Elect and immediate past President, plus an international Council.

ii: The President will begin his term at the Representative Assembly of the meeting of which he is president, after approval of the Membership.

iii: All the Executive Committee members must be approved by the Membership, and will serve for 4 years except for the Secretary-General and Hon. Treasurer who will have 8 years, for the sake of continuity.

iv: Executive Committee members will be proposed in writing and elected by the members' vote at a Representative Assembly.

$\mathrm{v}$ : The job of the Executive Committee is to make sure the Federation holds regular meetings and to have a Representative Assembly every 4 years.

b) If any subcommittee is required, the Executive Committee will appoint them, but all members must be representatives of a Federation Member Society.

c) Each WFSLMS congress will have its own Organizing Committee, separate from the Executive Committee

d) There will be two permanent standing subcommittees, one to look after the Bylaws, and one to look after the Federation's finances. The members will always come from the Executive Committee.

e) Federation Representative Assembly

i: There will be a Federation Representative Assembly every 4 years.

ii: The Agenda of the Assembly must contain acceptance of the Minutes of the previous Assembly, the President's report, the Treasurer's report, and the election of the new Executive Committee members.

iii: A list of new Federation Member Societies may be presented at the Representative Assembly.

iv: Changes may be made to the Membership fees at the Assembly.

$\mathrm{v}$ : The location of the following Representative Assembly will be decided, and its President, who will then join the Executive Committee as President-Elect.

vi: The new Executive Committee will take over their posts

f) Meetings

i: The Federation President, or an elected representative from the Executive Committee, will chair all meetings.

ii: The Secretary-General must keep written records of all meetings (the Minutes). If the Secretary-General is not at a meeting, another member of the Executive Committee must take the minutes.

iii: If the vote at a meeting is tied, the President will always have the power to make the final decision.

iv: Voting at meetings will always be made by raising hands, except for secret voting for Executive Committee members. All Member Societies can vote by written proxy if they cannot attend a meeting.

g) Federation Projects

Federation projects shall be decided on a regular basis by the Executive Committee, and appended to these Bylaws as Schedule 1 below.

h) Funding

Funding of the Federation will be realized from fees charged for IMeLaS certification and accreditation as set out in the document "World Federation of Societies for Laser Medicine and Surgery Certification: Criteria for INTERNATIONAL MEDICAL LASER SPECIALISTS" attached hereto as Schedule 2. Additional funding will come from a share of any net profits from WFSLMS meetings, as in Article 5(f) below. 


\section{5: Congresses}

a) The Federation Congress will be held every 4 years at the same time and usually in the same place as the ISLSM meeting, and will be run by the congress organizing committee.

b) The choice for the next meeting in 4 years time, and its President, will be presented at each congress.

c) The written proposal for each congress must be sent to the Executive Committee, and must include a Representative Assembly.

d) The Organizing Committee must keep the Membership informed about their meeting, and must send out announcements to all the Membership at least one year in advance of the meeting.

e) Anyone who pays the Congress registration fee is entitled to attend the Congress, but only recognized representatives of Member Societies can attend the Representative Assembly and vote at it.

f) Each organizing committee is responsible for fixing their registration and other congress fees, and must report on the congress finances at least six months after the end of the congress. At least $50 \%$ of any profits from a congress must be paid into the Federation funds. The Executive Committee may offer funds in advance to a congress organizing committee to prepare announcements, et cetera, but these funds must be paid back after the congress.

g) The official language of all congresses will be English, although simultaneous interpretation may be offered by each congress organizing committee.

\section{6: Finances}

a) The Federation financial year is from January 1 st to December 31st of the same year.

b) The Hon. Treasurer is responsible for banking and managing the Federation funds.

c) If the Federation decides to make any investments, they must be in the Federation's name, and all profits from these investments belong to the Federation. All investments must be signed by both the Hon. Treasurer and the President.

d) If the Federation is closed down, any excess funds will be donated to a charity chosen by the Executive Committee.

e) The Federation will be organized as a non-profit group.

\section{7: Federation Newsletter}

The Federation will issue a Newsletter to keep the Membership informed about Federation events.

\section{8: Voting and Changes to the Bylaws}

a) Voting will be by the majority decision. In the event of a tied vote, the President has the power to make the final decision. If a Member Society representative cannot attend a meeting, they can send in their proxy vote in writing, and indicate who they wish to hold their vote (usually the President or Secretary-General).

b) Changes to the Bylaws

i: Changes to these Bylaws can only be made and voted on at a Representative Assembly.

ii: Any proposed change has to be made in writing to the Secretary-General at least 3 months before a Representative or Special Assembly. Any change has to be voted on at the meeting.

iii: These bylaws cannot be changed without an advance written note to the Secretary-General.

iv: Only if the majority of representatives (more than 50\% of those present who are entitled to vote) vote for any change, then the Bylaws can be changed.

\section{SCHEDULE 1 to the WFSLMS BYLAWS \\ Planned Projects of the World Federation of Societies for Laser Medicine and Surgery}

1. Grant Project for International Medical Laser License (GP-IMeLL)

2. International Project of Medical Laser Education \& Training (IP-MeLET)

3. International Project of New Laser Treatment (IP-NeLT)

4. International Supporting Project of Medical Laser Related Societies (ISP-MeLRS)

5. International Supporting Project of Medical Laser Related Industries (ISP-MeLRI)

6. International Project of Laser Blood Saving Campaign (IP-Laser B-SAC)

7. International Cooperation Project of World Official Organizations and Social Groups (ICP-WOOS)

\section{SCHEDULE 2 to the WFSLMS BYLAWS \\ World Federation of Societies for Laser Medicine and Surgery Certification Criteria for INTERNATIONAL MEDICAL LASER SPECIALISTS}

General Information

The WFSLMS will certify and grade candidates for International Medical Laser Specialist (IMeLaS) certification according to the following three criteria:

1: Attendance at, and Membership of, international laser societies and associations.

2: The candidate's experience in laser surgery and/or medicine since attaining membership of their respective laser societies.

3: The candidate's contributions to laser surgery and medicine through oral presentations at the congresses of their respective laser societies and associations, and their contributions to the laser medicine and surgery literature,

\section{Grading System}

The Grading System is tentatively divided into 4 ranks, namely Grades 4 to 1 , starting from the lowest to the highest grades. The ranks and titles of IMeLaS grading are as follows, from highest to lowest:

$1^{\text {st }}$ Grade: I-IMeLaS - Certified IMeLaS Instructor

$2^{\text {nd }}$ Grade: A-IMeLaS - Class A IMeLaS

$3^{\text {rd }}$ Grade: B-IMeLaS - Class B IMeLaS

$4^{\text {th }}$ Grade: C-IMeLaS - Class C IMeLaS 
Requirement for application to the appropriate grade (starting from the lowest)

See also Table 1 below. Please note that in the case of published articles, any article written as the first author will count as 2 oral contributions, and only as 1 oral contribution for the $2^{\text {nd }}$ or subsequent author of an article.

$4^{\text {th }}$ Grade, C-IMeLaS: The applicant must be a licensed medical doctor of the country or the region in which he or she is practicing.

- The applicant is required to be a Member in Good Standing of the International Society for Laser Surgery and Medicine (ISLSM).

- The applicant is required to pass an examination after participating in a course of instruction in laser safety, and a practical hands-on session.

$3^{\text {rd }}$ Grade, B-IMeLaS: In addition to the requirements for the $4^{\text {th }}$ Grade Certificate, the applicant must fulfil the following:

- At least 3 years of active membership of the ISLSM.

- At least 3 oral presentations at his or her respective international laser societies and/or associations, or literary contributions to recognized journals.

$2^{\text {nd }}$ Grade, A -IMeLaS: In addition to the requirements for the 3rd Grade Certificate, the applicant must fulfil the following:

- At least 6 years of active membership of international laser societies and/or associations.

- At least 6 oral presentations at his or her respective international laser societies and/or associations, or literary contributions to recognized journals.

- The applicant is required to submit medical records of 10 cases treated by the applicant with lasers. The records should include photographs to clearly show the aptitude and competence of the applicant.

- The applicant should have made at least one presentation at an international congress as a symposist, invited speaker, tutorial lecturer, keynote lecturer, or special lecturer.

$\mathbf{1}^{\text {st }}$ Grade, I-IMeLaS: In addition to the requirements for the $3^{\text {rd }}$ Grade Certificate, the applicant must fulfil the following:

- At least 10 years of active membership of the ISLSM.

- At least 10 oral presentations at his or her respective international laser societies and/or associations or literary contributions to recognized journals.

- At least 3 presentations at international meetings as a symposist, invited speaker, tutorial lecturer, keynote lecturer, or special lecturer.

Upgrade Policy

Upgrading from an existing grade to a higher grade is possible once the appropriate criteria have been fulfilled, including the length of active ISLSM Membership, and on payment of the appropriate fee (Table 2). It is possible to apply for initial certification at any grade from the $2^{\text {nd }}$ to the $4^{\text {th }}$ grades (A-IMeLaS - C-IMeLaS), but applicants for $1^{\text {st }}$ Grade certification (I-IMeLaS) must first hold an A-IMeLaS ( $2^{\text {nd }}$ Grade) certification. Notwithstanding the above, if a candidate joins the ISLSM as a Life Member, then the length of ISLSM membership criterion will be deemed to have been satisfied for all grades of IMeLaS certification.

\section{Renewal of Certification}

Certification at any grade is valid for 5 years, always provided the holder remains as a Member in Good Standing of the ISLSM After that 5-year period, a renewal fee will be required to maintain certification (Table 2). On upgrading from any grade to a higher one, the 5-year period of validity will start from the date of the upgrade.

Table 1: Certification criteria summarized

\begin{tabular}{c|c|c|c|c|c|c}
\hline Grade & $\begin{array}{c}\text { Medical Laser Safety Course } \\
\text { and Examination }\end{array}$ & $\begin{array}{c}\text { Hands-on } \\
\text { Session }\end{array}$ & $\begin{array}{c}\text { Membership of ISLSM } \\
\text { (minimum) }\end{array}$ & $\begin{array}{c}\text { Oral Presentations } \begin{array}{c}\text { Submission } \\
\text { \& Written Papers* }\end{array} \\
\text { of 10 Cases }\end{array}$ & $\begin{array}{c}\text { Symposia, } \\
\text { Special Lectures, Etc. }\end{array}$ \\
\hline C-IMeLaS & R & R & 0 years** & NR & NR \\
B-IMeLaS & R & R & 3 years & 3 & NR \\
A-IMeLaS & R & R & 6 years & 6 & NR \\
I-IMeLaS & R & R & 10 years & 10 & R \\
\hline
\end{tabular}

R: Required NR: Not required

$\dagger$ Must be first author of the oral presentation, but not necessarily the presenter

*First author of written article $=2$ oral presentations; $2^{\text {nd }}$ and following author of written article $=1$ oral presentation

** ISLSM membership required before certification can be issued

Table 2: Fee structure for ISLSM and IMeLaS (in US \$)

\begin{tabular}{|c|c|c|c|c|}
\hline Item & C-IMeLaS & B-IMeLaS & A-IMeLaS & I-IMeLaS \\
\hline ISLSM Admission Fee* & $\$ 50$ & $\$ 50$ & $\$ 50$ & $\$ 50$ \\
\hline ISLSM Annual Dues (with journal) & $\$ 100$ & $\$ 100(\mathrm{x} 3)$ & $\$ 100(x 6)$ & $\$ 100(\mathrm{x} 10)$ \\
\hline ISLSM Life Member ( $<60$ years of age $)$ & $\$ 1000$ & $\$ 1000$ & $\$ 1000$ & $\$ 1000$ \\
\hline ISLSM Life Member ( 60 years of age and over) & $\$ 400$ & $\$ 400$ & $\$ 400$ & $\$ 400$ \\
\hline Medical Laser Safety Training Fee & $\$ 100$ & $\$ 100$ & $\$ 100$ & $\$ 100$ \\
\hline Hands-on Training Fee & $\$ 100$ & $\$ 100$ & $\$ 100$ & $\$ 100$ \\
\hline Examination Fee & $\$ 300$ & $\$ 300$ & $\$ 300$ & $\$ 300$ \\
\hline IMeLaS Certification Fee & $\$ 500$ & $\$ 500$ & $\$ 500$ & $\$ 500$ \\
\hline IMeLaS Certification Fee Renewal (after 5 yr) & $\$ 300$ & $\$ 300$ & $\$ 300$ & $\$ 300$ \\
\hline Upgrade to Next Certification Level & $\$ 500$ & $\$ 500$ & $\$ 500$ & - \\
\hline
\end{tabular}

*Once only payment

\section{SCHEDULE 3 to the WFSLMS BYLAWS}

\section{New Committees of the World Federation of Societies for Laser Medicine and Surgery}

Executive Committee Membership Committee Bylaw Committee
Financial Committee

Scientific Program Committee

Congress Organizing Committee
License Committee

Education \& Training Committee

Industrial Support Committee
Laser B-SAC Committee

Official Organization Committee 